\title{
PENGARUH PEMBERIAN EKSTRAK TEH HIJAU (Camellia sinensis L.) TERHADAP PENURUNAN KADAR KOLESTEROL TOTAL TIKUS WISTAR (Rattus norvegicus) DIABETES INDUKSI ALOKSAN
}

\author{
Zufarisky Sarel, Kristina Simanjuntak \\ (Fakultas Kedokteran, Universitas Pembangunan Nasional Veteran Jakarta)
}

\begin{abstract}
Green Tea works as an anti-dyslipidemia due to chronic hyperglycemia of diabetes through its flavonoid content. The purpose of this study was to determine the effectiveness of green tea extracts on reducing the total cholesterol levels of alloxan-induced diabetes Wistar rats. The study design uses true experimental. Samples were 30 Wistar strain male white rats, aged 8-12 weeks, weighing \pm 200 grams. Green tea extract doses of 200, 400, and 800 $\mathrm{mg} / \mathrm{kg}$ body weight, and negative controls were given alloxan, and positive controls were given simvastatin. The treatment group except the normal group was injected with a dose of $125 \mathrm{mg} / \mathrm{kg}$ alloxan intraperitoneally and a high-fat feed. After 3 days blood from the tail was measured glucose using a glucometer and cholesterol with a spectrophotometer $\lambda=546 \mathrm{~nm}$, giving green tea extract for 16 days orally, then re-measuring blood cholesterol from the tail. The One Way Anova Test results show the effectiveness of green tea extract on reducing total cholesterol $(p=0,000)$. The results of the Post-Hoc Bonferroni test giving green tea extract at a dose of $400 \mathrm{mg} / \mathrm{kg}$ were comparable to simvastatin $(p=0.453)$ which best decreased total cholesterol levels close to normal values.
\end{abstract}

Keywords: Alloxan; Diabetic; Green Tea; Total Cholesterol

\begin{abstract}
Abstrak
Teh Hijau berfungsi sebagai anti-dislipidemia karena hiperglikemia kronis diabetes melalui kandungan flavonoidnya. Tujuan dari penelitian ini adalah untuk menentukan efektivitas ekstrak teh hijau dalam mengurangi kadar kolesterol total tikus diabetes Wistar yang diinduksi aloksan. Desain penelitian menggunakan eksperimen sejati. Sampel penelitian adalah 30 tikus putih jantan galur Wistar, umur 8-12 minggu, berat \pm 200 gram. Dosis ekstrak teh hijau 200, 400, dan $800 \mathrm{mg} / \mathrm{kg}$ berat badan, dan kontrol negatif diberikan aloksan, dan kontrol positif diberi simvastatin. Kelompok perlakuan kecuali kelompok normal diinjeksi dengan dosis aloksan $125 \mathrm{mg} / \mathrm{kg}$ secara intraperitoneal dan pakan berlemak tinggi. Setelah 3 hari darah dari ekor diukur glukosa menggunakan glukometer dan kolesterol dengan spektrofotometer $\lambda=546 \mathrm{~nm}$, memberikan ekstrak teh hijau selama 16 hari secara lisan, kemudian mengukur kembali kolesterol darah dari ekor. Hasil Uji One Way Anova menunjukkan efektivitas ekstrak teh hijau dalam mengurangi kolesterol total ( $p=$ 0,000). Hasil tes Post-Hoc Bonferroni yang memberikan ekstrak teh hijau dengan dosis 400 $\mathrm{mg} / \mathrm{kg}$ sebanding dengan simvastatin $(p=0,453)$ yang paling baik menurunkan kadar kolesterol total mendekati nilai normal.
\end{abstract}

Kata Kunci : Alloxan; Diabetes; Teh hijau; Total kolesterol

\section{PENDAHULUAN}

Diabetes merupakan kelompok gangguan pada sistem metabolisme dengan ciri khas hiperglikemia kronik akibat keabnormalan kerja atau sekresi insulin dan bisa kombinasi keduanya. ${ }^{1}$ WHO memprediksi sebanyak $71 \%$ kematian diakibatkan PTM (penyakit tidak menular) yaitu penyakit jantung dan pembuluh darah $40 \%$, keganasan $22 \%$, penyakit pernapasan kronik $9 \%$ serta diabetes sebesar $4 \% .^{2}$ Jumlah penderita diabetes paling 
banyak terdapat di Asia Tenggara dan wilayah Pasifik Barat dimana pada tahun 2014 berjumlah 422 juta orang mengidap diabetes. ${ }^{3}$ Riset kesehatan dasar memproyeksikan 16 juta penduduk Indonesia bahkan lebih akan terancam menderita penyakit penyerta akibat diabetes, yaitu : stroke, gagal ginjal dan jantung, kelumpuhan dan buta, serta yang paling fatal adalah kematian. Estimasi ini didasarkan oleh prevalensi jumlah pasien diabetes di Indonesia meningkat dari $6,9 \%$ tahun 2013 dan menyentuh $8,5 \%$ pada tahun $2018 .{ }^{4}$ Menurut International Diabetes Federation (IDF) 2017 Indonesia berada di urutan ke-6 di dunia dan menjadi peringkat ke-2 berjumlah 10,7 juta orang dengan DM setelah Cina dan diprediksi meningkat pada tahun 2045.,5 Hiperglikemia kronik meningkatkan risiko penyakit kardiovaskular dan penyakit lainnya, dimana penyakit ini menyumbang 35\% angka kematian tertinggi di Indonesia tahun 2016 dan akan terus meningkat pada tahun $2030{ }^{2}$

Klasifikasi diabetes secara umum ada 3 tipe yaitu tipe 1 di mana tidak ada sekresi insulin, tipe 2 resistensi reseptor terhadap insulin dan tipe gestasional. ${ }^{1,5}$ Komplikasi diabetes ada dua yaitu akut dan kronik, komplikasi kronik salah satunya adalah penyakit kardiovaskular. Dislipidemia adalah komplikasi pada diabetes terjadi karena kerja enzim lipase peka insulin sangat aktif akibat defisiensi atau berkurangnya sensitivitas reseptor insulin yang menyebabkan pembebasan asam lemak non esterifikasi, peningkatan produksi Apo B, peningkatan Very Low Density Lipoprotein dan Low Density Lipoprotein, penurunan High density Lipoprotein (HDL), hiperkolesterolemia, dan hipertrigliserida. ${ }^{7}$ Penyakit kardiovaskular dapat muncul karena proses aterosklerosis dan aterogenesis akibat dislipidemia dan obesitas yang sering muncul bersamaan dengan diabetes, hiperglikemia menyebabkan inflamasi di berbagai jaringan terutama jaringan adiposa yang mengaktifkan Toll Like Receptor (TLR) yang mengawali pembentukan plak lemak di pembuluh darah. ${ }^{8}$

Hipertrigliserida terjadi karena resistensi insulin yang dikompensasi dengan peningkatan sekresi insulin, tetapi tetap terjadi penurunan sinyal insulin yang mengakibatkan pelepasan asam lemak bebas yang diubah menjadi trigliserida (TG) lalu disekresikan dalam bentuk VLDL dari hepar. Peningkatan VLDL terjadi karena sekresi Apo B di hepatosit meningkat, sintesis de-novo lemak di hepar bertambah karena aktivitas Amp-Protein Activated Kinase dan Fosfoinositol 3-Kinase yang berkurang, serta aktivitas reseptor LDL yang menurun. Diabetes tipe 1 terjadi penurunan pembersihan VLDL dan peningkatan kerja Cholesterol Ester Transfer Protein(CETP). ${ }^{9}$ Hiperkolesterolemia dan peningkatan kilomikron terjadi akibat beberapa perubahan diantaranya; resistensi insulin di enterosit dan jaringan lain, aktivitas Lipoprotein Lipase (LPL) berkurang, peningkaran sekresi $A p o C_{3}$, peningkatan absorbsi kolesterol, dan penurunan eksresi kolesterol ke feses di lumen usus. ${ }^{9}$

Terapi farmakologi dislipidemia adalah obat golongan statin (lovastatin, atorvastatin, fluvastatin, pravastatin, simvastatin, dan rosuvastatin) mampu mengurangi kadar kolesterol LDL sebesar $18-55 \%$ dan trigliserida sebesar 7-30\%, serta menambah lipoprotein 
pengangkut kolesterol dari seluruh tubuh ke hati (HDL) sebesar 5-15\%. ${ }^{10}$ Statin bekerja dengan menurunkan katalisis sintesis kolesterol pada tahap awal karena menghambat secara kompetitif enzim HMG KoA reduktase. Kadar kolesterol yang rendah akibat kerja statin akan menginduksi sintesis reseptor LDL dan mengurangi kadar trigliserida $(<250$ $\mathrm{mg} / \mathrm{dl}$ ) akibat produksi VLDL di hati meningkat untuk membawa trigliserida di sepanjang sirkulasi. ${ }^{11}$ Pemberian statin memiliki efek samping seperti nyeri otot, lemah, dan depresi serta belum cukup untuk menurunkan resiko penyakit kardiovaskuler.

Terapi alternatif berupa pengobatan herbal lebih aman dan sedikit resiko efek sampingnya. tanaman herbal seperti temulawak, rosela, kemangi, mengkudu, jinten hitam, biji alpukat, kiwi, sirsak, delima, nanas, jeruk, salam, tin, dan teh hijau. Mekanisme herbal dalam memperbaiki profil lipid diantaranya yaitu, menghambat absorbsi dan sintesis kolesterol, menginduksi proses transport kolesterol yang berlebih ke hepar, dan meningkatkan eksresi kolesterol di hepar. ${ }^{12,13}$ Teh hijau (Camellia sinensis L.) yang paling umum dijumpai dan dikonsumsi masyarakat Indonesia sebagai minuman, yang bekerja sebagai antiobesitas melalui beberapa mekanisme yaitu; menghambat diferensiasi adiposit, lipogenesis, menurunkan berat badan, mengurangi absorbsi lemak, meningkatkan oksidasi beta dan termogenesis, serta memperbaiki profil lipid yang abnormal. ${ }^{14}$

Teh hijau terutama pada bagian daun mengandung komponen bioaktif seperti polifenol, flavonoid, asam amino, teaflavin, kafein, tearubigin, tanin, dan katekin. Kandungan katekin dalam teh varietas sinensis adalah katekin 0,07 gram/100 gram daun, terutama Epicatekin (EC) 1,13 gram/100 gram daun, Epikatekin Gallat (ECG) 1,35 gram/100 gram daun, Epigallokatekin (EGC) 2,38 gram/100 gram daun, dan Epigallokatekin Gallat (EGCG) 8,59 gram/100 gram daun, tanin 1,21 gram/ 100 gram daun, dan kafein 2,78 gram/ 100 gram daun. ${ }^{15}$ EGCG adalah katekin yang sangat kuat dengan sifatnya sebagai antioksidan, antihiperkolesterolemia, hipertensi, dan penyakit degeneratif lainnya. ${ }^{16}$ Mekanisme teh hijau sebagai agen hipokolesterolemik adalah dengan mengurangi kerja enzim HMG-KoA reduktase dan meningkatkan ekspresi reseptor LDL sehingga LDL berkurang, meningkatkan eksresi garam empedu yang mengandung gugus kolesterol melalui aktivasi enzim $7 \alpha$-hidrolase, mengurangi kelarutan misel garam empedu terhadap koloesterol yang ada di makanan saat memasuki usus sehingga absorbsi kolesterol bekurang, dan efek antioksidan yang dapat melindungi sel dari kerusakan terutama pada sel beta di organ

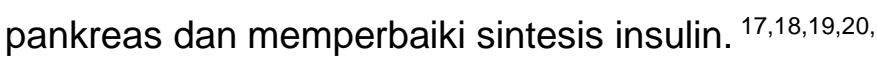

Penelitian Haidari et al (2012) menyimpulkan dosis ekstrak teh hijau $200 \mathrm{mg} / \mathrm{kgBB}$ efektif dalam menurunkan beberapa paramteter diantaranya adalah penurunan kolesterol total setelah 4 minggu pemberian ekstrak teh hijau padatikus diabetes induksi streptozotocin. Pemberian dengan dosis yang lebih tinggi dan durasi yang lebih lama mungkin dapat lebih menunjukkan hasil yang lebih baik. ${ }^{21}$ Penelitian Mostafa (2014) 
menyimpulkan ekstrak teh hijau dengan penambahan bubuk katekin pada tikus diabetes induksi aloksan $150 \mathrm{mg} / \mathrm{kgBB}$ secara signifikan mampu menurunkan kadar kolesterol, glukosa, dan memperbaiki kinerja ginjal dan hepar. ${ }^{22}$ Perbedaan pada penelitian ini adalah induksi diabetes menggunakan aloksan dosis $125 \mathrm{mg} / \mathrm{kgBB}$ dengan durasi pemberian ekstrak teh hijau selama 16 hari, serta variabel independent ekstrak teh hijau dengan dosis pembanding 200, 400, dan $800 \mathrm{mg} / \mathrm{kgBB}$. Berdasarkan hal tersebut peneliti berasumsi ekstrak teh hijau mampu menurunkan kadar kolesterol total penyakit diabetes mellitus, maka dilakukan penelitian ini dengan tujuan mengetahui efektivitas pemberian ekstrak teh hijau terhadap penurunan kadar kolesterol total tikus Wistar (Rattus norvegicus) diabetes yang diinduksi aloksan.

\section{METODE PENELITIAN}

Penelitian ini lolos uji pengkajian etik dan disetujui untuk dilaksanakan sesuai nomor etik B/2260/XII/2019/KEPK yang dikeluarkan oleh komisi etik Kedokteran UPN Veteran Jakarta. Desain penelitian ini adalah true experimental, dimana langkah awalnya dilakukan pengukuran lalu diberi perlakuan, dan di akhir penelitian dilakukan pengukuran kembali, serta hasil pengukuran antar kelompok dibandingkan. Lokasi penelitian di Lab farmakologi dan terapi Fakultas Kedokteran Universitas Padjajaran, Bandung, Jawa Barat. Identifikasi tanaman dilakukan di Lembaga IImu Pengetahuan Indonesia (LIPI), dan uji fitokimia dilakukan di Balai Penelitian Tanaman Rempah dan Obat (BALITTRO), Bogor, Jawa Barat.

Teknik pengambilan sampel menggunakan simple random sampling, dimana populasi sampel adalah seluruh tikus warna putih berjenis kelamin jantan (Rattus norvegicus) galur Wistar yang memiliki berat badan 150-200 gram, berumur 2-3 bulan, dan sehat yang ditandai dengan bergerak aktif dan tidak ada cacat secara fisik. Besar sampel dihitung menggunakan ketentuan rumus federer yaitu: $(n-1)(t-1) \geq 15$, dibagi menjadi 6 Kelompok perlakuan yaitu :

Kelompok K1 : perlakuan normal, pakan standar, aquades.

Kelompok K2 : Kontrol negatif, diinduksi aloksan

Kelompok K3 : Kontrol positif, diinduksi aloksan dan simvastatin

Kelompok K4 : Aloksan dan ekstrak teh hijau 200 mg/kgBB

Kelompok K5 : : Aloksan dan ekstrak teh hijau $400 \mathrm{mg} / \mathrm{kgBB}$

Kelompok K6 : Aloksan dan ekstrak teh hijau $800 \mathrm{mg} / \mathrm{kgBB}$

Kelompok perlakuan kecuali K1 diberi pakan tinggi lemak.Jumlah sampel minimal tiap kelompok adalah 4 tikus, untuk mencegah drop out ditambah satu tikus menjadi 5 tikus perkelompok dengan total sampel 30 tikus Wistar. Instrumen yang digunakan adalah alat berupa kandang tikus berserta kelengkapan pemberian pakan dan minum, spektrofotometer, 
timbangan analitik, sonde lambung, scalpel, alcohol swabs, sentrifugator, mortar dan pestle, mikropipet, gelas ukur $100 \mathrm{ml}$, gelas kimia, spatula, sarung tangan, disposable syringe, lampu duduk, dan tabung reaksi. Bahan penelitian menggunakan ekstrak teh hijau dalam 3 dosis, simvastatin, pakan standar tikus, aloksan monohidrat, akuades, reagen-kit kolesterol, dan pakan tinggi lemak.

Prosedur penelitian, pembuatan larutan aloksan dengan dosis $125 \mathrm{mg} / \mathrm{kgBB}$, simvastatin 0,9 mg/kgBB/hari, serta ekstrak teh hijau 200, 400, dan 800 mg/kgBB. Pemilihan dosis $200 \mathrm{mg} / \mathrm{kgBB}$ sebagai acuan dari penelitian sebelumnya Haidari et al (2012)dan dosis pembanding kelipatan ganda 400 dan $800 \mathrm{mg} / \mathrm{kgBB}$ untuk melihat efek yang ditimbulkan dari dosis yang lebih tinggi.Pembuatan ekstrak teh hijau dengan teknik maserasi yang diawali dengan pengeringan daun teh hijau dalam oven $50^{\circ} \mathrm{C}$ selama 1-2 hari, lalu dilarutkan dengan etanol 70\% dan didiamkan selama 2-3 hari, dan langkah terakhir adalah disaring serta dirotavapor selama 4 jam pada suhu $50^{\circ} \mathrm{C}$ sampai diperoleh ekstrak teh hijau.

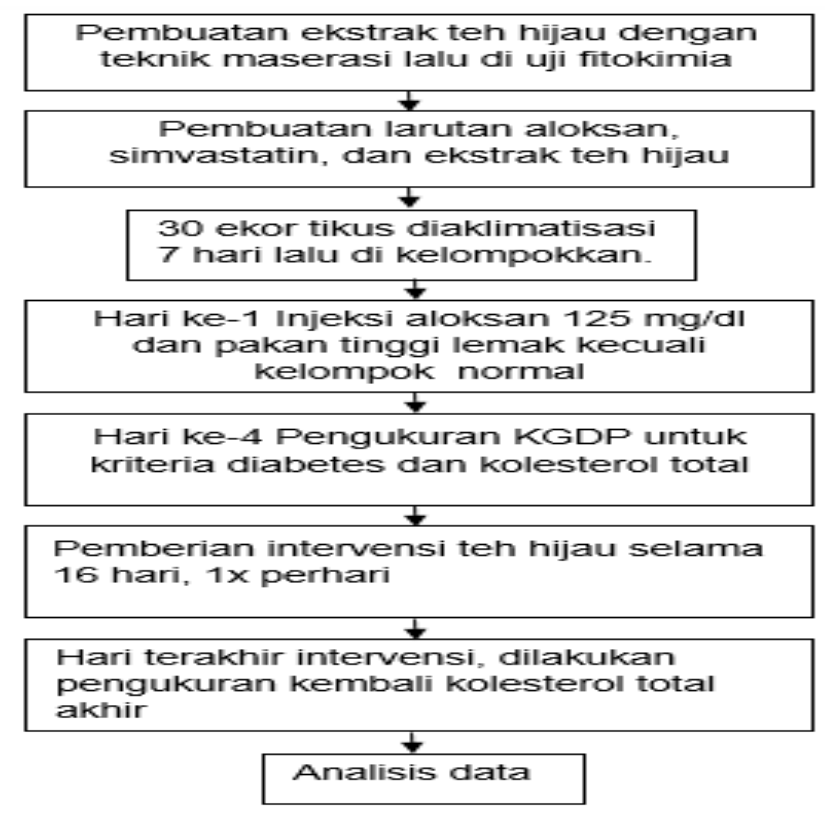

Bagan 1. Prosedur Penelitian

Pemberian perlakuan, perlakuan dilakukan oleh peneliti sendiri dan dibantu oleh laboran yang sudah terlatih, semua kelompok tikus dilakukan proses adaptasi terhadap lingkungan baru atau aklimatisasi selama 7 hari, lalu dikelompokkan secara acak dan diinjeksikan aloksan intraperitoneal dan pakan tinggi lemak personde. Setelah 3 hari, semua sampel tidak diberi makan (dalam kondisi puasa), lalu darah diambil dari ekor dilakukan untuk mengukur kuantitas glukosa darah puasa (KGDP) agar kondisi diabetes tercapai dengan kriteria KGDP lebih dari $110 \mathrm{mg} / \mathrm{dl}$ menggunakan glukometer dan kolesterol dengan spektrofotometer $\lambda=546 \mathrm{~nm}$ sebelum perlakuan. Semua alat ukur sudah dikalibrasi terlebih dahulu sebelum digunakan. Peningkatan kadar kolesterol jika kolesterol total lebih tinggi 
dibandingkan dengan kelompok kontrol normal. Selama 16 hari diberikan perlakuan teh hijau dan diakhir penelitian dilakukan pengambilan darah dari ekor untuk mengetahui kadar kolesterol total setelah pemberian perlakuan.

Analisis data menggunakan uji One Way ANOVA agar mengetahui perbedaan antar kelompok, dimana data yang digunakan adalah selisih kolesterol total antara sebelum dengan setelah diberikan ekstrak teh hijau. Data dianalisislanjutan memakai uji post hoc Bonferroni menggunakan statistik SPSS versi 22. Data diuji terlebih dahulu distribusi normal menggunakan uji saphirowilk dan varian data homogen menggunakan uji levene, jika data tidak berdistribusi normal dilakukan uji Kruskal wallis.

\section{HASIL PENELITIAN}

Uji fitokimia bersifat kualitatif untuk mengetahui apakah terdapat kandungan senyawa pada teh hijau yang memiliki aktivitas biologis, ekstrak dilarutkan menggunakan etanol $70 \%$ yang dilakukan di Balai Penelitian Tanaman Rempah dan Obat (BALITTRO) yang berlokasi di daerah Bogor. Teknik maserasi digunakan untuk mengekstrak teh hijau pada penelitian ini. Hasil uji ditunjukkan pada tabel 1.

\section{Tabel 1. Hasil Uji Fitokimia Ekstrak Teh hijau}

\begin{tabular}{clc}
\hline $\begin{array}{c}\text { Kandungan Senyawa Ekstrak } \\
\text { Teh Hijau }\end{array}$ & $\begin{array}{c}\text { Hasil } \\
\text { Pengujian }\end{array}$ & $\begin{array}{c}\text { Metode } \\
\text { Pengukuran }\end{array}$ \\
\hline Alkaloid & Positif $(+)$ & \\
\hline Saponin & Positif $(+)$ & \\
\hline Tanin & Positif $(+)$ & Kualitatif \\
\hline Fenolik & Positif $(+)$ & \\
\hline Flavonoid & Positif $(+)$ & \\
\hline Triterpenoid & Positif $(+)$ & \\
\hline Steroid & Positif $(+)$ & \\
\hline Glikosida & Positif $(+)$ & \\
\hline
\end{tabular}

Tabel 2 menunjukkan kadar glukosa darah puasa yang diukur menggunakan glukometer setiap kelompok setelah pemberian aloksan, KGDP tertinggi pada kelompok perlakuan ekstrak teh hijau $800 \mathrm{mg} / \mathrm{kgBB}$ sebesar $489 \mathrm{mg} / \mathrm{dl}$ dan terendah kelompok ekstrak teh hijau $400 \mathrm{mg} / \mathrm{kgBB}$ sebesar $214 \mathrm{mg} / \mathrm{dl}$. Hasil uji One way ANOVA KGDP setelah induksi aloksan $(p=0,000)$ yang menggambarkan bahwa terdapat perbedaan minimal antar dua kelompok. KGDP yang meningkat ditunjukkan dengan perbedaan yang signifikan antara kelompok induksi aloksan dengan kelompok normal $(p=0,40)$ dan kelompok lain yang diinduksi aloksan menunjukkan KGDP yang sebanding dengan kelompok kontrol aloksan yaitu kelompok simvastatin, teh hijau 200 dan 400 mg/kgBB, serta kelompok teh hijau 800 $\mathrm{mg} / \mathrm{kgBB}$ berbeda secara signifikan dengan kelompok normal $(p=0,000)$. 
Tabel 2. Rata- Rata Kadar Glukosa Darah Puasa (KGDP)

\begin{tabular}{cccc}
\hline Kelompok & $\begin{array}{c}\text { Usia } \\
\text { (Minggu) }\end{array}$ & $\begin{array}{c}\text { Rerata setelah } \\
\text { Induksi Aloksan } \\
\text { (mg/dl) }\end{array}$ & $\begin{array}{c}\boldsymbol{P} \text { Value } \\
\text { ANOVA }\end{array}$ \\
\hline Kontrol Normal & 8 & $80,75 \pm 11,17$ & \\
\hline Aloksan & 8 & $264,5 \pm 45,29$ & \\
\hline Simvastatin & 8 & $250 \pm 120,57$ & 0,000 \\
\hline Teh Hijau 200 & 8 & $245,75 \pm 110,73$ & \\
\hline Teh Hijau 400 & 8 & $214, \pm 20,46$ & \\
\hline Teh Hijau 800 & 8 & $489 \pm 62,91$ & \\
\hline
\end{tabular}

Gambar 1 menunjukkan perbedaan rerata kadar kolesterol plasma darah sebelum dan sesudah diberikan intervensi, kolesterol dihitung memakai alat spektrofotometer dengan $\lambda=546 \mathrm{~nm}$.

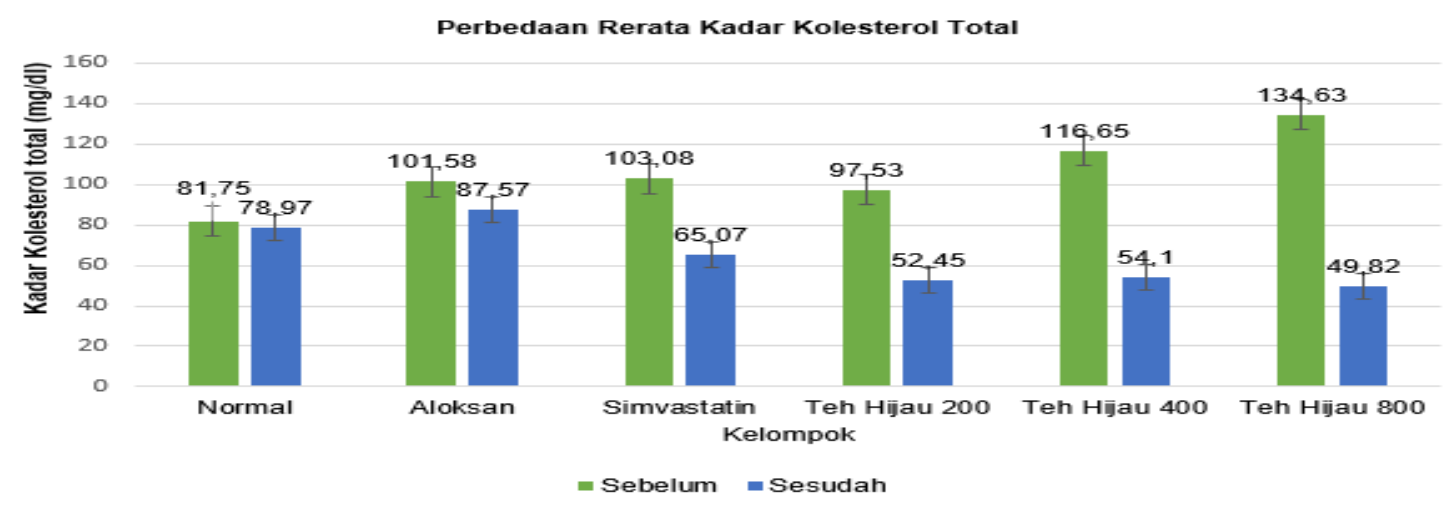

Gambar 1. Perbedaan rerata Kadar Kolesterol Total Sebelum dan Sesudah Perlakuan

Kolesterol pada kelompok intervensi meningkat dibandingkan dengan kelompok normal tanpa pemberian perlakuan sama sekali. Perubahan kadar kolesterol terjadi cukup besar pada kelompok diabetes yang diberikan teh hijauyaitu kelompok ekstrak teh hijau 200 $\mathrm{mg} / \mathrm{kgBB}$ sebesar 45,08 mg/dl, kelompok ekstrak teh hijau $400 \mathrm{mg} / \mathrm{kgBB}$ sebesar 62,55 $\mathrm{mg} / \mathrm{dl}$, dan kelompok ekstrak teh hijau $800 \mathrm{mg} / \mathrm{kgBB}$ sebesar $84,81 \mathrm{mg} / \mathrm{dl}$.

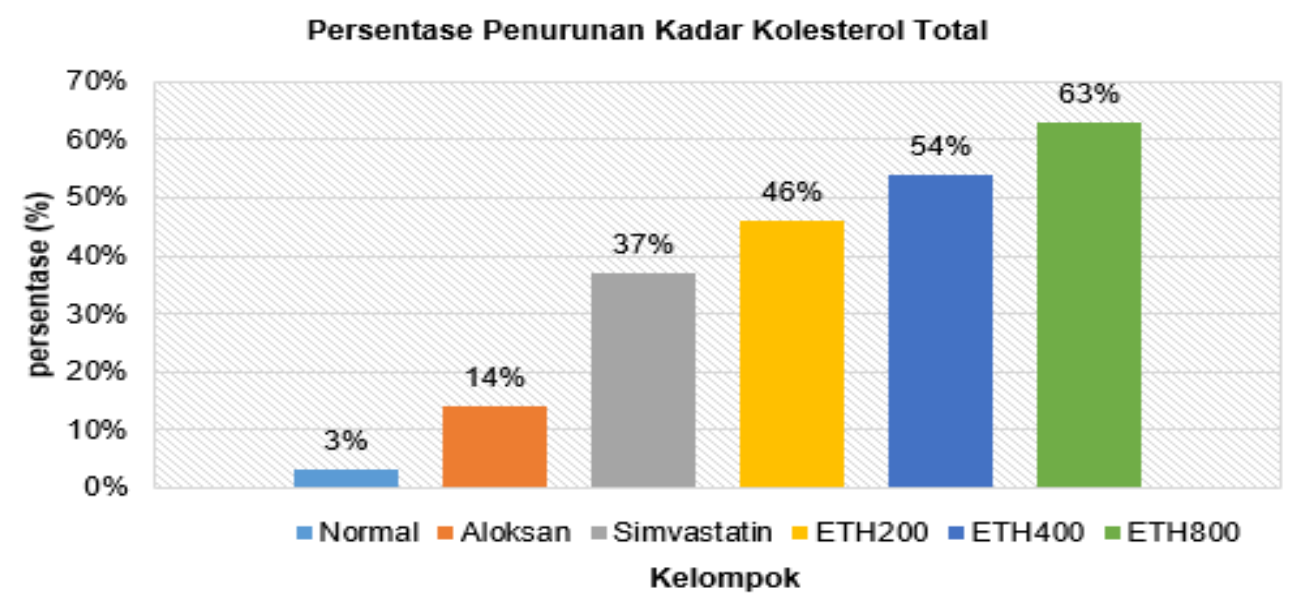

Gambar 2. Persentase Penurunan Kadar Kolesterol Total 
Persentase penurunan kuantitas kolesterol total setelah diberikan teh hijau (Gambar 2.) menunjukkan penurunan kadar kolesterol terkecil sebesar 3\% kelompok normal dan terbesar adalah kelompok teh hijau $800 \mathrm{mg} / \mathrm{kgBB}$ sebesar $63 \%$. Urutan persentase penurunan kadar kolesterol total kelompok perlakuan teh hijau dari yang terkecil berturutturut adalah kelompok teh hijau $200 \mathrm{mg} / \mathrm{kgBB}$, lalu $400 \mathrm{mg} / \mathrm{kgBB}$, serta tertinggi 800 $\mathrm{mg} / \mathrm{kgBB}$. Hasil uji One Way ANOVA diperoleh nilai $(\mathrm{p}=0,000)$, dimana nilai plebih kecil dari 0,05 dengan kesimpulan minimal ada perbedaan yang bermakna antar dua kelompok. Perbedaan yang bermakna ini diuji dengan posthoc Bonferroni agar ditemukannya perbedaan bermakna antar kelompok.

Kelompok normal berbeda secara signifikan dengan kelompok ekstrak teh hijau 200, 400, dan 800 mg/kgBB. Kelompok aloksan tidak berbeda bermakna dengan teh hijau 200 $\mathrm{mg} / \mathrm{kgBB}$, tetapi bermakna perbedaanya dengan kelompok ekstrak teh hijau 400 dan 800 $\mathrm{mg} / \mathrm{kgBB}$. Kelompok simvastatin tidak berbeda signifikan dengan ekstrak teh hijau 200 dan $400 \mathrm{mg} / \mathrm{kgBB}$, berbeda signifikan dengan ekstrak teh hijau $800 \mathrm{mg} / \mathrm{kgBB}$. Kelompok ekstrak teh hijau $200 \mathrm{mg} / \mathrm{kgBB}$ tidak berbeda signifikan dengan kelompok teh hijau $400 \mathrm{mg} / \mathrm{kgBB}$ dan berbeda signifikan dengan kelompok teh hijau $800 \mathrm{mg} / \mathrm{kgBB}$. Kelompok ekstrak teh hijau $400 \mathrm{mg} / \mathrm{kgBB}$ tidak berbeda signifikan dengan kelompok simvastatin, teh hijau 200 dan $800 \mathrm{mg} / \mathrm{kgBB}$ dan berbeda signifikan dengan kelompok aloksan

\section{PEMBAHASAN}

Uji fitokimia ekstrak teh hijau yang dilakukan pada penelitian ini mengandung kandungan bioaktif salah satunya adalah flavonoid dan tanin, sesuai dengan yang dikatakan oleh Rohdiana (2015) dimana daun teh hijau mengandung asam fenolat, flavonoid, tanin, vitamin B1, B2, dan C, dimana flavonoid terbanyak adalah katekin sebanyak 0,35 gram/100 gram daun terutama epikatekin, epigallokatekin, epikatekin gallat, dan epigallokatekin gallat. ${ }^{15}$ EGCG adalah katekin yang sangat kuat dengan sifatnya sebagai antioksidan, antihiperkolesterolemia, hipertensi, dan penyakit degeneratif lainnya. ${ }^{16}$

Semua kelompok perlakuan mengalami peningkatan KGDP (tabel 2) setelah induksi aloksan dibandingkan dengan kelompok kontrol normal, sesuai penelitian Ojiako et al (2015), dan memenuhi kriteria tikus diabetes karena memiliki KGDP lebih dari $110 \mathrm{mg} / \mathrm{dll}{ }^{23}$ KGDP normal tikus Wistar sebesar 50-109 mg/dl. ${ }^{24}$ Hiperglikemia terjadi karena ikatan spesifik aloksan dengan sel $\beta$ pankreas pada Glucose Transporter-2 (GLUT-2) lalu memasuki sitoplasma sel $\beta$ pankreas. Aloksan di sitoplasma sel menyebabkan influks $\mathrm{Ca}^{2+}$, sehingga terjadi depolarisasi berlebih di mitokondria yang diikuti deplesi energi sel. ${ }^{25}$ Struktur aloksan yang mirip dengan glukosa menghambat kerja enzim glukokinase sel $\beta$ pankreas dan menyebabkan proses redoks terjadi berulang. Proses reduksi aloksan yang berulang ini menghasilkan metabolit berupa asam dialurik yang mengurangi jumlah 
glutation (GHS), asam dialurik akan mengalami proses autooksidasi kembali menjadi aloksan dan menyebabkan enzim yang melindungi sel dari paparan ROS berkurang dan menginduksi kerusakan sel $\beta$ pankreas. ${ }^{26}$ Perbedaan KGDP tiap kelompok induksi aloksan terjadi karena adanya variasi ketahanan individu terhadap aloksan ${ }^{27}$.

Kenaikan kadar kolesterol total terlihat pada semua kelompok perlakuan setelah induksi aloksan (gambar 1) dibandingkan dengan kelompok kontrol normal sesuai dengan penelitian Nainggolan et al (2012) kenaikan kadar kolesterol total 4 hari setelah induksi aloksan pada kelompok model diabates ${ }^{28}$. Diabetes dapat menyebabkan dislipidemia yang salah satunya menyebabkan peningkatan kadar kolesterol total plasma darah karena enzim lipase sensitif insulin menjadi sangat aktif akibat defisiensi insulin atau resistensi insulin dan menyebabkan pelepasan asam lemak bebas ke darah. ${ }^{7}$ Penyakit diabetes juga ditandai dengan gejala polidipsi, poliuri, dan polifagi disertai hiperglikemia dimana terjadi peningkatan nafsu makan. ${ }^{29}$ Kelompok perlakuan selain kelompok normal diberikan pakan tinggi lemak untuk membuat efek hiperglikemia kronis dan profil lipid menjadi abnormal dengan memperparah resistensi insulin dan mengganggu regenerasi sel beta pankreas. ${ }^{30}$ Perbedaan kadar kolesterol yang berbeda tiap kelompok setelah induksi aloksan karena hyperlipidemia dan metabolisme lemak berkorelasi dengan keparahan dan periode kondisi hiperglikemia serta status terkontrol atau tidaknya penyakit diabetes. Hiperlipidemia memiliki relasi dengan diabetes tidak terkontrol, dikatakan hiperglikemia terkontrol jika KGDP dan glukosa darah pos prandial mendekati kadar normal. Menurut Penelitian Dave et al (2019) menyimpulkan $\mathrm{HbA1C}$ dan KGDP berhubungan langsung dengan kadar kolesterol dan trigliserida, di mana KGDP yang tinggi atau tidak terkontrol menunjukkan kadar kolesterol yang meningkat ${ }^{31}$.

Berdasarkan gambar 1 kadar kolesterol kelompok perlakuan setelah 16 hari perlakuan mengalami penurunan terutama kelompok yang diberi ekstrak teh hijau. Kolesterol kelompok aloksan juga menurun karena aloksan menyebabkan kerusakan sel beta pankreas akibat produksi ROS dan $\mathrm{H}_{2} \mathrm{O}_{2}$ tetapi sifat aloksan yang kurang stabil, maka regenerasi sel beta pankreas sudah mulai terjadi dalam beberapa hari setelah induksi aloksan dan membuat produksi insulin membaik. ${ }^{32}$ Penelitian Nainggolan et al (2012) juga menunjukkan tikus diabetes induksi aloksan tanpa pemberian perlakuan nanocurcumin mengalami penurunan kadar kolesterol setelah 11 hari perlakuan sebesar 33\%. ${ }^{28}$ Kelompok induksi aloksan dengan perlakuan simvastatin menunjukkan penurunan kadar kolesterol total sebesar $37 \%$ (gambar 2) karena simvastatin adalah obat dislipidemia paling efektif menghambat sintesis kolesterol denga mengurangi aktivitas enzim HMG-KoA reduktase. ${ }^{10}$ Statin bekerja bersaing dengan enzim HMG-KoA reduktase pada tahap pertama sintesis kolesterol dan salah satu obat golongan statin yang kuat adalah simvastatin. ${ }^{11}$ Kelompok simvastatin tidak berbeda bermakna dengan kelompok teh hijau selain $800 \mathrm{mg} / \mathrm{kgBB}$ yang berarti efektivitas 
simvastatin sebanding dengan ekstrak teh hijau dosis dosis dua ratus dan empat ratus $\mathrm{mg} / \mathrm{kgBB}$ dalam mengurangi jumlah kolesterol darah.

Pemberian teh hijau sangat baik dalam mengurangi kolesterol dibandingkan tikus yang mengidap penyakit diabetes tanpa pengobatan sesuai penelitian Haidari (2012) dan Mostafa (2014). ${ }^{21,22}$ Dosis $200 \mathrm{mg} / \mathrm{kgBB}$ belum cukup menurunkan kadar kolesterol penyakit diabetes karena tidak signifikan berbeda dengan kelompok diabetes yang tidak terobati, tidak sesuai penelitian Haidari et al (2012) menyebutkan ekstrak dari teh hijau pada $200 \mathrm{mg} / \mathrm{kgBB}$ lebih efektif daripada setengah dosis dibawahnya. ${ }^{21}$ Kelompok pemberian ekstrak teh hijau 400 $\mathrm{mg} / \mathrm{kgBB}$ berbeda signifikan dengan kelompok aloksan, yang menandakan dosis ini efektif dalam menurunkan kadar kolesterol total penyakit diabetes serta efeknya hampir sama kelompok teh hijau dosis $800 \mathrm{mg} / \mathrm{kgBB}$ dan simvastatin $(p=0,453)$. Ekstrak teh hijau mengandung katekin yang dapat menghambat enzim HMG-KoA reduktase serta meningkatkan ekspresi reseptor kolesterol LDL, ekskresi kolesterol dalam bentuk garam empedu juga meningkat ke dalam lumen usus dengan mengaktifkan enzim $7 \alpha$-hidrolase yang meningkatkan konversi kolesterol ke garam empedu, katekin terutama EGCG akan menghambat kelarutan misel pada garam empedu terhadap kolesterol sehingga absorbsi kolesterol pada diet tinggi lemak dapat berkurang. ${ }^{17,18,19,20}$ Teh hijau juga akan meningkatkan ekspresi reseptor LDL melalui Sterol Regulate Element Binding Protein-1 (SERBP-1) dan mRNA enzim penekan sintesis kolesterol. $^{33}$

Efek antioksidan yang dapat mencegah kerusakan sel terutama sel beta pankreas dan merangsang produksi kembali hormon insulin, karena kandungan arabinogalaktan tipe II yang mengaktivasi jalur cAMP-Akt untuk produksi insulin. ${ }^{20}$ Kandungan lain seperti tanin, alkaloid, dan saponin juga menginduksi regenerasi sel $\beta$ pankreas. ${ }^{34}$ Ekstrak teh hijau 800 $\mathrm{mg} / \mathrm{kgBB}$ juga dapat mengurangi kolesterol lebih baik di penyakit diabetes karena berbeda secara signifikan dengan kelompok aloksan dan kelompok simvastatin, serta dosis teh hijau 200. Efeknya sebanding dengan dosis teh hijau $400 \mathrm{mg} / \mathrm{kgBB}$ karena semakin tinggi dosis teh hijau akan semakin baik efeknya sesuai yang disampaikan pada penelitian Haidari et al (2012). ${ }^{21}$ Penurunan yang sangat kuat ini dikarenakan ikatan katekin dengan asam amino enzim HMG-KoA reduktase lebih kuat dibandingkan ikatan oleh simvastatin. ${ }^{35}$ Tetapi konsumsi ekstrak teh hijau harus dibawah dosis toksik (LD50), dimana dosis kurang dari $5000 \mathrm{mg} / \mathrm{kgBB}$ pada mencit masih aman untuk dikonsumsi. ${ }^{36}$ Dosis $5000 \mathrm{mg} / \mathrm{kgBB}$ setara dengan 38,79 gram $/ 70 \mathrm{kgBB}$ manusia, sedangkan dosis $800 \mathrm{mg} / \mathrm{kgBB}$ pada tikus setara dengan 8,96 gram/70kgBB manusia, dikhawatirkan jika mengkonsumsi ekstrak teh hijau dosis ini secara berlebihan akan melebihi dosis toksiknya.

Penelitian ini juga terdapat keterbatasan yaitu tikus model diabetes diinduksi aloksan yang menyebabkan kerusakan sel beta pankreas bersifat kurang stabil, uji fitokimia bersifat kualitatif sehingga tidak bisa menentukan jumlah spesifik flavonoid karena keterbatasan 
biaya. Kelebihan dari penelitian ini adalah pengambilan darah tikus berasal dari ekornya saja tanpa harus diterminasi, kelompok diabetes selain diinduksi aloksan juga diberi pakan tinggi lemak agar dapat memperlama efek kerusakan sel beta pankreas sehingga kenikan KGDP dapat lebih stabil.

\section{SIMPULAN DAN SARAN}

Berdasarkan hasil analisis data dan pembahasan dapat disimpulkan ekstrak teh hijau (Camellia sinensis L.) dapat menurunkan kadar kolesterol total tikus Wistar (Rattus norvegicus) diabetes yang diinduksi aloksan $(\mathrm{p}=0,000)$, dengan dosis sangat baik adalah $400 \mathrm{mg} / \mathrm{kgBB}$ hampir setara obat simvastatin $(p=0,453)$ dan mendekati nilai normal kadar kolesterol total. Disarankan untuk penelitian lebih lanjut pemisahan EGCG dari ekstrak teh hijau, pemeriksaan profil lipid secara periodik, dan pemeriksaan histopatologi organ jantung dan hepar untuk melihat efek protektif teh hijau pada keadaan diabetes mellitus.

\section{DAFTAR PUSTAKA}

1. PERKENI. Konsensus Pengelolaan dan Pencegahan Diabetes Melitus Tipe 2 di Indonesia. Konsensus Pengelolaan dan Pencegah Diabetes Melitus Tipe 2 di Indones. 2015;1-93.

2. World Health Organization. Monitoring Health For SDGs Sustainable Development Goals. World Heal Organ [Internet]. 2018;1-86. Available from: https://www.who.int/gho/publications/world_health_statistics/2018/en/

3. World Health Organization. Global Report on Diabetes. Isbn [Internet]. 2016;978:88. Available from: http://www.who.int/about/licensing/\%5Cnhttp://apps.who.int/iris/ bitstream/10665/204871/1/9789241565257_eng.pdf

4. Kementerian Kesehatan. CEGAH, CEGAH, dan CEGAH: Suara Dunia Perangi Diabetes [Internet]. 2018 p. 2018-20. Available from: http://www.depkes.go.id/article/view/18121200001/prevent-prevent-and-prevent-thevoice-of-the-world-fight-diabetes.html

5. IDF. IDF DIABETES ATLAS. Lancet [Internet]. 2017;1-150. Available from: http://fmdiabetes.org/wp-content/uploads/2018/03/IDF-2017.pdf

6. IDF. IDF Diabetes Atlas Ninth. Dunia IDF [Internet]. 2019;1-14. Available from: http://www.idf.org/about-diabetes/facts-figures

7. Schofield JD, Liu Y, Rao-Balakrishna P, Malik RA, Soran H. Diabetes Dyslipidemia. Diabetes Ther [Internet]. 2016;7(2):203-19. Available from: https://doi.org/10.1007/s13300-016-0167-x

8. Rodriguez-Araujo G, Nakagami H. Pathophysiology of cardiovascular disease in diabetes mellitus. Cardiovasc Endocrinol Metab [Internet]. 2018;7(1):4-9. Available 
from: https://doi.org/10.1097/XCE.0000000000000141

9. Hirano T. Pathophysiology of diabetic dyslipidemia. J Atheroscler Thromb [Internet]. 2018;25(9):771-82. Available from: https://doi.org/10.5551/jat.RV17023

10. PERKI. panduan tata laksana dislipidemia 2017. J Kardiol Indones [Internet]. 2017;(April 2017):1-80. Available from: http://www.inaheart.org/upload/file/Pedoman_ tatalksana_Dislipidemia.pdf

11. Gilman G\&. Dasar Farmakologi Terapi. 10th ed. Joel. G. Hardman \& Lee E. Limbird, Gilman AG, editors.

12. Ji X, Shi S, Liu B, Shan M, Tang D, Zhang W, et al. Bioactive compounds from herbal medicines to manage dyslipidemia. Biomed Pharmacother [Internet]. 2019;118(July):109338. Available from: https://doi.org/10.1016/j.biopha.2019.109338

13. Rabie'ah, Carlos FK, Griselda J, Sari WP, Kusumawardhani S, Tendean M. Tatalaksana \{Terkini\} \{Dislipidemia\}. J Kedokt Meditek [Internet]. 2014;20(54):28-33. Available from: http://ejournal.ukrida.ac.id/ojs/index.php/Ked/article/view/1022

14. Salomo H, Busman H, Apriliana E. Pengaruh Pemberian Metformin dan Ekstrak Daun Teh Hijau pada Penurunan Berat Badan Tikus Putih ( Rattus norvegicus ) Galur Sprague Dawley dengan Diet Tinggi Lemak. Med J Lampung Univ [Internet]. 2018;7(2):65-70. Available from: https://juke.kedokteran.unila.ac.id/index.php/ majority/article/view/1853

15. Rohdiana D. Teh: 2015;(December). Available from: https://www.researchgate.net/ publication/286460235

16. Leslie PJ, Gunawan S. Daun, Uji fitokimia dan perbandingan efek antioksidan pada teh hijau, teh hitam, dan teh putih (Camellia sinensis) dengan metode DPPH (2, 2difenil-1- pikrilhidrazil). Tarumanagara Med J [Internet]. 2019;Vol. 1, No(2):383-8. Available from: https://journal.untar.ac.id/index.php/tmj/article/view/3841

17. Adelina R. Mekanisme Katekin Sebagai Obat Antidislipidemia (Uji In Silico). Bul Penelit Kesehat [Internet]. 2018;46(3):147-54. Available from: https://doi.org/10.22435/bpk.v46i3.899

18. Ahmad RS, Butt MS, Sultan MT, Mushtaq Z, Ahmad S, Dewanjee S, et al. Preventive role of green tea catechins from obesity and related disorders especially hypercholesterolemia and hyperglycemia. J Transl Med [Internet]. 2015;13(1):1-9. Available from: https://doi.org/10.1186/s12967-015-0436-x

19. Kobayashi M, Ikeda I. Mechanisms of inhibition of cholesterol absorption by green tea catechins. Food Sci Technol Res [Internet]. 2017;23(5):627-36. Available from: https://doi.org/10.3136/fstr.23.627

20. Jin-Ming M, Shi-yu C, Xin Lin W, Ren You G, Yuan Feng W, Shu Xian C, et al. Effects and mechanisms of tea for the prevention and management of diabetes mellitus and 
diabetic complications: An updated review. Antioxidants [Internet]. 2019;8(170):1-25. Available from: https://doi.org/10.3390/antiox8060170

21. Haidari F, Shahi MM, Zarei M, Rafiei H, Omidian K. Effect of green tea extract on body weight, serum glucose and lipid profile in streptozotocin-induced diabetic rats: A dose response study. Saudi Med J [Internet]. 2012;33(2):128-33. Available from: https://www.researchgate.net/publication/235637252\%0A\%0A

22. Mostafa, El-Sayed U. Effect of green tea and green tea rich with catechin on blood glucose levels, serum lipid profile and liver and kidney functions in diabetic rats. Jordan J Biol Sci. 2014;7(1):7-12.

23. Ojiako OA, Chikezie PC, Ogbuji AC. Blood glucose level and lipid profile of alloxaninduced hyperglycemic rats treated with single and combinatorial herbal formulations. J Tradit Complement Med [Internet]. 2015;6(2):1-9. Available from: http://dx.doi.org/10.1016/j.jtcme.2014.12.005

24. Rahmawati FC, Djamiatun K, Suci N. Pengaruh yogurt sinbiotik pisang terhadap kadar glukosa dan insulin tikus sindrom metabolik. J Gizi Klin Indones [Internet]. 2017;14(1):10. Available from: https://doi.org/10.22146/ijcn.19379

25. Nugraha MR, Hasanah AN. Metode Pengujian Aktifitas Antidiabetes. Farmaka [Internet]. 2018;16(3):28-34. Available from: http://jurnal.unpad.ac.id/farmaka/article/ viewFile/17298/pdf \%0A\%0A

26. Ighodaro OM, Adeosun AM, Akinloye OA. Alloxan-induced diabetes, a common model for evaluating the glycemic-control potential of therapeutic compounds and plants extracts in experimental studies. Med [Internet]. 2017;53(6):365-74. Available from: https://doi.org/10.1016/j.medici.2018.02.001

27. Cahyaningrum, P, L, Yuliari, S, A, M, Suta, I, B, P. Uji Aktivitas Antidiabetes dengan ekstrak buah Amla( Phyllanthus Emblica L) pada mencit Balb/c yang diinduksi aloksan. J Vocat Heal Stud [Internet]. 2019;6-10:53-8. Available from: https://www.google.com/url?sa=t\&rct=j\&q=\&esrc=s\&source=web\&cd=3\&cad=rja\&uact $=8 \&$ ved =2ahUKEwio1 bq57qvpAhVA83MBHY6YCA8QFjACegQIAxAB\&url=https\%3A $\% 2 \mathrm{~F} \% 2 \mathrm{Fe}-$

journal.unair.ac.id\%2FJVHS\%2Farticle\%2Fdownload\%2F16841\%2F9055\&usg=AOv Vaw3jsV9guDYy0yF9aormrrir\%0A

28. Nainggolan H, Saragih H, Ricky, D R, Hutapea, A M. Nanocurcumin Sebagai Penurun Kadar Glukosa Darah Pada Tikus Wistar Diabetes. Pros Simp Fis Nas XXV. 2012;189-200.

29. ADA. Standards Of Medical Care in Diabetes-2017", The Journal Of Clinical And Applied Research and Education. J Clin Apllied Res Educ. 2017;40(1):1-135.

30. Guo X xuan, Wang Y, Wang K, Ji B ping, Zhou F. Stability of a type 2 diabetes rat 
model induced by high-fat diet feeding with low-dose streptozotocin injection. $\mathrm{J}$ Zhejiang Univ Sci B [Internet]. 2018;19(7):559-69. Available from: https://doi.org/10.1631/jzus.B1700254

31. Dave M, Gupta AK, Patel P, Heernath H. Correlation between Fasting Blood Sugar Level, HbA1C Level and Serum Lipid Levels in Type 2 Diabetes Mellitus Patients. Int J Contemp Med Res [IJCMR]. 2019;6(7).

32. King A, Austin A. Animal Models of Type 1 and Type 2 Diabetes Mellitus [Internet]. Second Edi. Animal Models for the Study of Human Disease. Elsevier Inc.; 2017. 245-65 p. Available from: http://dx.doi.org/10.1016/B978-0-12-809468-6/00010-3

33. Maiti S, Nazmeen A, Medda N, Patra R, Ghosh TK. Flavonoids green tea against oxidant stress and inflammation with related human diseases. Clin Nutr Exp [Internet]. 2019;24:1-14. Available from: https://doi.org/10.1016/j.yclnex.2018.12.004

34. Hardoko, AB B, Sasmito, Bambang B, Halim Y. Antidiabetic Activity of Herbal Green Tea Extract from White Mangrove (Avicennia marina) Leaves towards Blood Glucose Level of Diabetic Wistar Rats (Rattus novergicus) Hardokoa,. Int J Food Stud [Internet]. 2019;8:43-52. Available from: https://www.iseki-foodejournal.com/ojs/index.php/e-journal/article/view/553

35. Isnawati A, Adelina R. Studi Docking Molekuler Catechin Gallate, Epicatechin Gallate, Gallocatechin Gallate, dan Epigallocatechin Gallate sebagai Obat Dislipidemia. J Kefarmasian Indones [Internet]. 2015;5(1):25-32. Available from: https://doi.org/10.22435/jki.v5i1.4083.25-32

36. Gupta J, Afzal M. In Vivo Assesment Of Possible Toxicity Risks Of Green Tea Extract In Mice. Int J Bioassays [Internet]. 2015;4(2):3636-41. Available from: https://www.google.com/url?sa=t\&rct=j\&q=\&esrc=s\&source=web\&cd=\&ved=2ahUKE wjutrqetP_pAhUW6nMBHa-mDQsQFjAAegQIBhAB\&url=https\%3A\%2F\%2Fwww .ijbio.com\%2Farticles\%2Fin-vivo-assessment-of-possible-toxicity-risks-of-green-teaextract-in-mice.pdf\&usg=AOvVaw1PTK4L88 